Spring 1-1-2018

\title{
The Myth of U.N. Collective Security
}

Mohamed S. Helal

Follow this and additional works at: https://scholarlycommons.law.emory.edu/eilr-recent-developments

\section{Recommended Citation}

Mohamed S. Helal, The Myth of U.N. Collective Security, 32 Emory Int'I L. Rev. Recent Dev. 1063 (2018).

Available at: https://scholarlycommons.law.emory.edu/eilr-recent-developments/ 9

This Essay is brought to you for free and open access by the Journals at Emory Law Scholarly Commons. It has been accepted for inclusion in Emory International Law Review Recent Developments by an authorized administrator of Emory Law Scholarly Commons. For more information, please contact law-scholarlycommons@emory.edu. 


\title{
THE MYTH OF U.N. COLLECTIVE SECURITY
}

\author{
Mohamed S. Helal*
}

\section{INTRODUCTION}

2017 was a busy year for the United Nations Security Council. It held 296 formal meetings during which it adopted sixty-one Resolutions, passed twentyseven Presidential Statements, and issued ninety-three Press Statements. These meetings, resolutions, and statements addressed a variety of issues, ranging from the politically profound, such as the North Korean nuclear weapons program, to the prosaic and the procedural, such as receiving routine reports from the U.N. bureaucracy, renewing the mandates of longstanding U.N. peacekeeping operations, and electing Judges to the International Court of Justice. ${ }^{1}$ Whenever it acted promptly to preempt the outbreak of war or to resolve an international crisis, the Security Council was applauded for its effectiveness and its members were commended for their unity in confronting threats to international peace and security. For instance, the Security Council's role in diffusing the crisis that ensued following the Presidential elections in The Gambia in the early days of 2017 was hailed by France's Permanent Representative to the United Nations as an "excellent example" of "preventive diplomacy." Similarly, the U.S. Permanent Representative Nikki Haley praised the members of the Security Council for imposing sanctions on North Korea in response to its missile tests, which showed that "[t]hey have selflessly placed our collective security above their individual political and economic interests. They have won the gratitude of the international community for their responsible actions."3

But the Security Council did not take action in response to a number of crises and conflicts, including situations that constituted serious threats to peace and security. Six times during 2017, one of the five Permanent Members

* Assistant Professor of Law, Moritz College of Law \& Faculty Affiliate, Mershon Center for International Security Studies - The Ohio State University. For reading a draft of this Essay and for her support, I thank Cinnamon Carlarne. I also thank Dr. Christiane Ahlborn for her comments and suggestions on an earlier version of this Essay. I also acknowledge, with much gratitude, Steven Darnell and Andrea Hearon for their research assistance. Obviously, all errors are mine alone.

1 February 2018 Monthly Forecast, SEC. CounCIL ReporT (Jan. 31, 2018). http://www. securitycouncilreport.org/monthly-forecast/2018-02/.

2 Provisional Verbatim Record, U.N. SCOR, 70th Sess., 7866th mtg. at 5, U.N. Doc. S/PV.7866 (Jan. 19, 2017).

3 Provisional Verbatim Record, U.N. SCOR, 70th Sess., 8118th mtg. at 5, U.N. Doc. S/PV.8118 (Nov. 29, 2017). 
of the Security Council exercised its veto to prevent the Council from taking action. ${ }^{4}$ Five of those vetoes were cast by Russia (which was joined on one occasion by China) to prevent Security Council action against Syria, while the remaining veto was cast by the United States to prevent the Security Council from reaffirming the status of East Jerusalem as occupied territory following President Donald Trump's recognition of Jerusalem as the capital of Israel. ${ }^{5}$ Commenting on the failure of the Security Council to act against the Syrian regime, Ambassador Haley declared that "Russia and China made an outrageous and indefensible choice today. They refused to hold Bashar AlAssad's regime accountable for the use of chemical weapons. They turned away from defenceless men, women and children who died gasping for breath when Al-Assad's forces dropped their poisonous gas." 6 Conversely, after vetoing the draft resolution on Jerusalem, Ambassador Haley condemned the Council for considering a resolution that would have censured the United States and announced that "[w]hat we witnessed today in the Security Council is an insult. It will not be forgotten."7

The trading of diplomatic invective among the members of the Security Council is not uncommon. ${ }^{8}$ Nor is it uncommon for commentators and political pundits to denounce the Council for its perceived failure to resolve international crises and to rail against the Permanent Members for exercising their veto power. ${ }^{9}$ Even U.N. officialdom has, albeit on rare occasions, chided

4 As is well known, the Permanent Members of the Security Council are: China, France, Russia, the United Kingdom, and the United States. Each of these states holds a veto power, which means that if any of those states votes against a draft Security Council resolution, that draft resolution will not be adopted by the Council, even if it is supported by the remaining fourteen members of the Council. Voting System and Records, U.N. SEC. COUNCIL, http://www.un.org/en/sc/meetings/voting.shtml (last visited Apr. 13, 2018).

5 February 2018 Monthly Forecast, supra note 1.

6 Provisional Verbatim Record, U.N. SCOR, 70th Sess., 7893rd mtg. at 4, U.N. Doc. S/PV.7893 (Feb. 28, 2017).

7 Provisional Verbatim Record, U.N. SCOR, 70th Sess., 8139th mtg. at 5, U.N. Doc. S/PV.8139 (Dec. 18, 2017).

8 For instance, the United States attempts to exempt U.S. service members from being prosecuted by the International Criminal Court (I.C.C.) elicited vocal criticism from the Council's non-permanent members and from the broader U.N. membership. Canada's ambassador was reported to have been "livid" and described the decision of the Council to exempt peacekeepers from the jurisdiction of the I.C.C. as an "abuse of power." See David Bosco, Five to Rule Them All: The UN Security Council AND the MaKing of the Modern WORLD 222 (2009).

9 Daoud Kuttab, US Hypocrisy at the Security Council, JoRDAN TIMES (Dec. 20, 2017), http://www. jordantimes.com/opinion/daoud-kuttab/us-hypocrisy-security-council; Afrah Nasser, The Unfolding UN Failure in the Yemen War, ATLANTIC COUNCIL (Sept. 21, 2017), http://www.atlanticcouncil.org/blogs/ menasource/the-unfolding-un-failure-in-the-yemen-war; Megan Opera, The Syrian Crisis Again Illustrates Why the UN is Such a Failure, FEDERALIST (Dec. 8, 2016), http://thefederalist.com/2016/12/08/syrian-crisisillustrates-united-nations-failure/; Palestinians Slam 'Unacceptable' US Veto of Jerusalem UN Resolution, ALARABIYA (Dec. 19, 2017), http://english.alarabiya.net/en/News/middle-east/2017/12/19/Palestinians-slam- 
the Permanent Members for preventing the Security Council from effectively discharging its responsibility to maintain international peace and security. The U.N. High Commissioner for Refugees, for instance, recently lamented the Council's failure to "broker peace" in Myanmar, Somalia, Afghanistan, and elsewhere, and warned of "the direct impact of these failures, every day, on the lives of tens of millions of people, uprooted and forced to abandon their homes." ${ }^{10}$ More graphically, in his final speech to the U.N. Human Rights Council, the outgoing High Commissioner for Human Rights opined that "so long as the veto is used by them to block any unity of action when it is needed the most, when it could reduce the extreme sufferings of innocent people, then it is they-the permanent members-who must answer before the victims." 11

This Essay argues that criticism of this sort of the Security Council and of its Permanent Members is misplaced and reflects a widespread misunderstanding of the Council's structure, nature, and purpose. Many scholars and commentators misperceive the Security Council as a "collective security" mechanism. ${ }^{12}$ The purpose of the Security Council is imagined to be the protection of states against aggression. ${ }^{13}$ Because the U.N. Charter conferred upon the Security Council the "primary responsibility for the maintenance of international peace and security," ${ }^{14}$ it is assumed that the Council is duty-bound to intervene to protect states against threats to their

unacceptable-US-veto-of-Jerusalem-UN-resolution-.html; Somini Sengupta, United Nations’ Reputation Slips as Four-Year War in Syria Drags On, N.Y. TiMES (Mar. 12, 2015), https://www.nytimes.com/2015/03/13/ world/middleeast/aid-agencies-fault-un-security-council-on-syria-conflict.html; Unbecoming Bias, JoRDAN TIMES (Oct. 26, 2017), http://jordantimes.com/opinion/editorial/unbecoming-bias.

10 'Failure to Broker Peace' Hinders Solutions to Displacement, UN Refugee Chief Tells Security Council, U.N. NEWS CTR. (Nov. 2, 2017), https://news.un.org/en/story/2017/11/569862-failure-broker-peacehinders-solutions-displacement-un-refugee-chief-tells.

11 UN Rights Chief Blasts Veto Use Amid 'Human Slaughterhouse', AL-JAzEera (Feb. 26, 2018), https://www.aljazeera.com/news/2018/02/rights-chief-blasts-veto-human-slaughterhouses-180226183904000. html.

12 Oscar Schachter, Authorized Uses of Force by the United Nations and Regional Organizations, in LAW AND ForCE IN THE NEW INTERNATIONAL ORder 66 (Lori Damrosch \& David Scheffer eds. 1991) (It is often referred to as collective security, an expression not used in the Charter, but widely regarded as the principal goal of the United Nations.); Jose Alvarez, Judging the Security Council, 90 AM. J. INT’L L. 1, 2 (1996) (Some scholars view the UN Charter as a "hierarchical collective security scheme with the Council at its apex.”); Thomas Franck, Collective Security and UN Reform: Between Necessity and the Possible, 6 CHI. J. INT’L L. 597, 605 (2006) (explaining that the "postwar system of collective security" was designed by the UN's founders in 1943-1945); Ved Nanda, Preemptive and Preventive Use of Force, Collective Security, and Human Security, 33 DENV. J. INT’L L. \& PoL'y 7 (2004) (arguing that the U.N. Charter established a system where "the collective security concept was the touchstone of the new emerging world order").

13 John Norton Moore, Toward a New Paradigm: Enhanced Effectiveness in United Nations Peacekeeping, Collective Security, and War Avoidance, 37 VA. J. INT'L L. 811, 814 (1997) (The "original central purpose of the organization was collective security against aggression in order to end war.”).

14 U.N. Charter art. 24. 
survival, security, or independence. ${ }^{15}$ Many scholars presume, as John Yoo does, that the U.N. Charter offered the U.N. Member States the following bargain: "if they gave up war as a tool of international politics, a supranational government will prevent threats to their security." 16

This Essay challenges this misperception. It argues that the Security Council is not a collective security mechanism. ${ }^{17}$ Rather, the Security Council is designed to operate like a Great Power Concert, akin to the Concert of Europe that was established by the leading European powers of the nineteenth century to oversee and manage European affairs. ${ }^{18}$ The Security Council was not intended to provide a guarantee of collective protection against aggression nor was it created to function as an enforcer of international law. Like a Great Power Concert, the principal purpose of the Security Council is to contribute to the maintenance of peaceful relations between the most powerful states in the international system. Therefore, the Security Council was created to provide a forum through which the Great Powers of the post-World War II era could coordinate their policies and jointly manage the international system. To incentivize the Great Powers to both join the United Nations and remain within the organization, these powers were granted permanent membership on the Security Council and were endowed with the ability to veto any proposed Security Council action that they deemed would threaten or jeopardize their security or interests. The veto, as this Essay shows, is legibus solutus: a power unrestrained by law.

Accordingly, if the Permanent Members agree on a course of action, as they did following Iraq's invasion of Kuwait, the Council can take effective measures to resist aggression or enforce international law. ${ }^{19}$ If, however, the

15 Robert Delahunty, Paper Charter: Self-Defense and the Failure of the United Nations Collective Security System 56 CATH. U. L. REV. 871, 871-872 (2007) (The U.N. members accepted the prohibition on using force on the "belief that the Charter's scheme of collective security would afford them at least as much protection for their national security as they had agreed to relinquish.”).

16 John Yoo, Point of Attack: Preventive War, International Law, and Global Welfare 133 (Oxford Univ. Press 2014).

17 See generally Mohamed Helal, Am I My Brother's Keeper? The Reality, Tragedy, and Future of Collective Security, 6 HARV. NAT’L SEC. J. 383 (2015).

18 Lauri Mãlksoo, Great Powers Then and Now: Security Council Reform and Responses to Threats to Peace and Security, in United Nations Reform AND the New Collective SeCurity 109 (Peter Danchin \& Horst Fischer eds., Cambridge Univ. Press 2010) (Noting that "the Security Council is not that different from previous Holy Alliances and other Great Power directorates of European/world affairs”); see also David Bosco, Assessing the UN Security Council: A Concert Perspective, 20 Global Governance 545 (2014).

19 S.C. Res. 678 (Nov. 29, 1990); S.C. Res. 667 (Sept. 16, 1990); S.C. Res. 666 (Sept. 13, 1990) S.C. Res. 665 (Aug. 25, 1990); S.C. Res. 664 (Aug. 18, 1990); S.C. Res. 662 (Aug. 9, 1990); S.C. Res. 660 (Aug. 2, 1990). 
interests of the Permanent Members diverge, such as during the Cold War or the ongoing Syrian civil war, or if the Permanent Members are disinterested, such as during the 1994 Rwandan Genocide, the Security Council will be inactive. ${ }^{20}$ The Council's frequent inability to intervene to prevent crises, resist acts of aggression, or enforce international law is, therefore, not a "failure" at all. Rather, in its many instances of inaction and non-intervention, the Security Council is functioning exactly as it was intended to operate. ${ }^{21}$

This Essay is composed of four parts. Part I outlines the defining characteristics of both collective security mechanisms and a great power concert. Part II identifies the policy purposes the Security Council was intended to serve, and Part III describes the powers and prerogatives of the Security Council as enshrined in the U.N. Charter and recounts the negotiating history of the Charter to demonstrate that the Council was intended to function as a Great Power Concert and not as a collective security mechanism. Finally, in Part IV, I argue that the institutional structure and powers of the Security Council and the privileges enjoyed by its Permanent Members reflect the belief of the United Nations' founders that the surest guarantee of world order is the maintenance of a balance of power between the most powerful states in the international system. This assumption, I argue, remains valid and relevant today. Despite the inevitable injustices that flow from a world founded on the balance of power, I argue that preserving a balance between the greatest powers in the international system and respecting their vital interests remains indispensable for the functioning of international law and for effective global governance.

\section{The SeCurity Dilemma AND SeCURITY Regimes}

War is the perennial challenge to world order. In an anarchic world, which lacks a central governing authority that exercises the powers of international lawmaking and law-enforcement and enjoys a monopoly on the legitimate use of force, the threat of war remains a pervasive and ineffaceable feature of

20 Douglas Anglin, Rwanda Revisited: Search for the Truth, 56 INT’L J. 149, 156 (2000); Apology Over Rwanda Genocide, N.Y. Times (Apr. 16, 2014), https://www.nytimes.com/2014/04/17/world/africa/apologyover-rwanda-genocide.html.

21 Ian Hurd, The UN Security Council and the International Rule of Law, CHINESE J. INT’L POLITICS 1, 6-7 (2014) (Hurd makes a similar claim, noting that the veto "leads to apparent paralysis when the permanent members disagree with each other, as was evident throughout the Cold War and more recently over the Iraq invasion of 2003 and the Syrian war since 2011. But this is by design; the alternative would be to empower the Council to act against the strongest states, an eventuality which would likely cause them to actively oppose or abandon the organization.”). 
world politics. $^{22}$ This impels states to amass power to, at least, ensure their survival and security or, more ambitiously, to acquire and secure access to natural resources, to enlarge their spheres of political and economic influence, or to expand their territory. ${ }^{23}$ This behavior unlocks the security dilemma: As a state becomes more powerful, its neighbors become apprehensive about its increasing capabilities because they are unsure about whether their neighbor's intentions are defensive or offensive. ${ }^{24}$ Accordingly, states will seek to acquire greater power to deter their increasingly powerful neighbor. ${ }^{25}$ These states may do so either by enlarging their military capabilities or by forging alliances to offset the growing power of their neighbor. ${ }^{26}$ Detecting this behavior by its neighbors, the first state, which is also unsure whether its neighbors' increasing power is intended for offensive or merely defensive purposes, redoubles its efforts to acquire greater power to protect itself against its neighbors, who in turn become increasingly anxious and seek to further expand their capabilities. ${ }^{27}$ This spiraling dynamic of insecurity is omnipresent in world politics and has caused untold tragedies in human history. ${ }^{28}$

To address this phenomenon, states have routinely established mechanisms designed to alleviate the security dilemma. These mechanisms, which international relations theorists call "security regimes," fulfill a wide range of functions. $^{29}$ For instance, these regimes facilitate communication between states to provide assurances about their intentions and to assuage the uncertainty that fuels the security dilemma. ${ }^{30}$ Security regimes may also

22 Benjamin Frankel, Restating the Realist Case: An Introduction, in REALISM: RESTATEMENTS AND RENEWALS xv-xvi (Benjamin Frankel ed., 1996) ("A major reason why the fierce competition for security may lead to war is the profound uncertainty states have about each other's intentions ... the absence of a central authority to adjudicate disputes and enforce verdicts, heightens anxiety, suspicion, and fear.”).

23 See John H. Herz, International Politics in the Atomic Age 231-32 (Columbia Univ. Press 1959).

24 Id.

25 Id

26 Id. at 232-33.

27 See generally John Herz, Idealist Internationalism and the Security Dilemma, 2 WORLD POL. 157 (1950) (providing a classical depiction of the "security dilemma").

${ }_{28}$ The security dilemma provides at least a partial explanation for the outbreak of conflicts ranging from systemic wars, such as World War I, to regional conflicts, such as the Balkan wars that followed the break-up of the former Yugoslavia. The logic of the security dilemma also explained to a large extent the dynamic of the Cold War and other strategic rivalries such as the relationship between India and Pakistan. See Shiping Tang, The Security Dilemma: A Conceptual Analysis, 18 SECURITY STUD. 587, 588-89 (2009).

29 Robert Jervis, Security Regimes, 36 INT’L ORG. 357, 357 (1982).

30 An example of a security regime established to enhance communication and policy coordination between adversaries appears in Article VII of the 1979 Egyptian-Israeli Peace Treaty, which provides for the establishment of a liaison system "to resolve any problem that may arise in the course of implementation, and refer other unresolved matters to the higher military authorities of the two countries respectively for 
provide mechanisms through which states can coordinate their foreign policies or devise common responses to crises that threaten their security or interests. ${ }^{31}$ Non-aggression pacts, in which neighbors and adversaries promise not to attack each other, are another form of security regimes that mitigate the uncertainty that generates the security dilemma. ${ }^{32}$ Security regimes could also take the form of an ad hoc alliance against a specific adversary, such as the Quadruple Alliance that defeated Napoleon, ${ }^{33}$ or an alliance to defend against a specific threat, such as the Holy Alliance that was created by the conservative monarchies of nineteenth-century Europe to preempt and suppress popular revolutions. ${ }^{34}$ On rare historical occasions, states may achieve an advanced level of political and economic integration and reach a degree of social kinship and cultural affinity whereby relations between those states evolve into what Karl Deutsch called a "security community" in which the security dilemma is all but eliminated and the likelihood of conflict is at a minimum. ${ }^{35}$

Among the security regimes that states have created to deter enemies and confront aggressors are collective security mechanisms. ${ }^{36}$ Since time immemorial, states have resorted to collective security to combine their capabilities to deter and repel attackers. ${ }^{37}$ Collective security mechanisms come in different shapes and sizes. They could be embedded within inter-state

consideration. It is also intended to prevent situations resulting from errors or misinterpretation on the part of either Party.” Treaty of Peace, Egypt-Isr., Mar. 26, 1979, 1138 U.N.T.S. 17855.

31 The European Common Foreign and Security Policy and the institutional apparatus that oversees its implementation is an example of a security regime that facilitates communication between its members and enables them to adopt common foreign policy positions. See JolyOn HowORTH, THE SECURITY AND DEFENCE POLICY IN THE EUROPEAN UNION 1-2 (2007).

32 See Melvin Small \& J. David Singer, Formal Alliances, 1816-1965: An Extension of the Basic Data, 6 J. PEACE RES. 257, 270 (1969).

33 Édouard Driault, The Coalition of Europe Against Napoleon, 24 AM. HIST. REV. 603, 615-17 (1919).

34 Roy Bridge \& Roger Bullen, The Great Powers and the European States System 1814191428 (2013).

35 See Karl Deutsch, Political Community and the North Atlantic Area 5 (Princeton Univ. PRESs 1957). Before its abolishment and the transferring of its functions to the European Union, the western European Union was an example of a security community.

36 This section defines collective security and identifies its essential characteristics. This is necessary because, as international relations scholars have noted, "even though the concept has been invoked with increasing frequency by scholars and politicians alike, the debate is muddied by differing interpretations of what collective security is ...." Charles Kupchan \& Clifford Kupchan, Concerts, Collective Security, and the Future of Europe, 16 INT'L SEC. 114, 115 (1991).

37 Michael Glennon \& Allison Hayward, Collective Security and the Constitution: Can the Commander in Chief Power be Delegated to the United Nations?, 82 GEO. L.J. 1573, 1576 (1994) (citing examples of human collectivities, such as states, city-states, or nations, that joined forces to resist foreign aggression and noting that "[t]he notion that nations could combine to create a collective force is ages old"). 
organizations, such as the League of Arab States, ${ }^{38}$ or they could be formed pursuant to inter-state agreements and operate independently of any particular institutional setting, such as the collective security provisions in the treaties of the Peace of Westphalia. ${ }^{39}$ Collective security mechanisms could also be bilateral or multilateral. ${ }^{40}$ Whatever their size, composition, or institutional form, all collective security mechanisms share a set of common features. First and foremost, collective security is based on the ancient adage: unus pro omnibus, omnes pro uno-one for all, and all for one. This means that the members of a collective security organization agree that "a war against one state is, ipso facto, considered a war against all." 41 This commitment to consider an attack against one as an attack against all is often codified in a legal instrument. To count as a genuine collective security mechanism that commitment of a united response against aggression must be ironclad, it "permits no ifs or buts." 42

38 The Arab Joint Defense Agreement is an example of a collective security arrangement that is embedded within an inter-state organization. Treaty of Joint Defense and Economic Cooperation Between the States of the Arab League, art. II, June 18, 1950. Article II of this treaty states:

The Contracting States consider any [act of] armed aggression made against any one or more of them or their armed forces, to be directed against them all. Therefore, in accordance with the right of self-defense, individually and collectively, they undertake to go without delay to the aid of the State or States against which such an act of aggression is made, and immediately to take, individually and collectively, all steps available, including the use of armed force, to repel the aggression and restore security and peace.

Id.

39 Sebastian Schmidt, To Order the Minds of Scholars: The Discourse of the Peace of Westphalia in International Relations Literature, 55 INT’L STUD. Q. 601, 608-09 (2011).

40 In a sense, a bilateral collective security arrangement may also be called a common defense pact. For example, Article 2 of the Joint Defence Agreement between Egypt and Syria states:

The two Contracting States consider any armed attack against either State or its forces as an attack against both. Accordingly, and in exercise of the right of individual or collective selfdefence, they undertake to hasten to each other's assistance in case of an attack and to take immediately all appropriate measures and use all the means at their disposal, including armed force, to repel the attack and to restore security and peace.

Joint Defence Agreement, Egypt-Syria, art. 2, Oct. 20, 1955, 126 U.N.T.S. 3461.

Article 4 of the African Union Non-Aggression and Common Defence Pact is an example of a multilateral collective security arrangement embedded within an international organization:

a) States Parties undertaker to provide mutual assistance towards their common defence and security vis-à-vis any aggression or threats of aggression.

b) States Parties undertake, individually and collectively, to respond by all available means to aggression or threats of aggression against any Member State.

African Union Non-Aggression and Common Defence Pact, art. 4, Mar. 7, 2017.

41 John Gerard Ruggie, Constructing the World Polity 108 (Routledge 1998).

42 Inis Claude, Swords Into Plowshares: The Problems and Progress of International ORGANIZATION 258-59 (1956). 
Collective security, therefore, operates like domestic law enforcement. Like a police force that is duty-bound to provide protection to individuals against threats or attacks against their person or property, a collective security mechanism operates on the basis of a legal commitment of mutual assistance and protection among its members. ${ }^{43}$ The North Atlantic Treaty that established the North Atlantic Treaty Organization (NATO) is an archetypical example of this guarantee to protect the members of a collective security mechanism against aggression. ${ }^{44}$ It stipulates that:

\section{Article 5}

The Parties agree that an armed attack against one or more of them in Europe or North America shall be considered an attack against them all and consequently they agree that, if such an armed attack occurs, each of them, in exercise of the right of individual or collective selfdefence recognised by Article 51 of the Charter of the United Nations, will assist the Party or Parties so attacked by taking forthwith, individually and in concert with the other Parties, such action as it deems necessary, including the use of armed force, to restore and maintain the security of the North Atlantic area.

Any such armed attack and all measures taken as a result thereof shall immediately be reported to the Security Council. Such measures shall be terminated when the Security Council has taken the measures necessary to restore and maintain international peace and security. ${ }^{45}$

Another feature of collective security is that it is non-discriminatory. Its members commit to aid each other against any and all aggressors. ${ }^{46}$ The guarantee of protection is unequivocal and is not limited to a specific enemy. ${ }^{47}$ Even if it is understood that, as a matter of policy, a collective security mechanism is created to counter or deter a specific enemy, as a matter of law, these security regimes offer a general, non-discriminatory guarantee of

43 Kenneth Thompson, Collective Security Reexamined, 47 AM. POL. ScI. REV. 753, 755 (1953) (“The idea of collective security is simple, challenging and novel. It would do for the international society what police action does for the domestic community. If the individual is threatened or endangered in municipal society, he turns to the legitimate agents of law enforcement, the police.”).

44 North Atlantic Treaty, Apr. 4, 1949, 63 Stat. 2241, 34 U.N.T.S. 243.

45 Id. art. 5.

46 Keith Shimko, International Relations: Perspectives, Controversies and Readings 66-67 (2014).

47 This distinguishes collective security from alliances. As Glenn Snyder explains, "alliances are formal associations of states for the use (or nonuse) of military force, in specified circumstances, against states outside their own membership ... . Their primary function is to pool military strength against a common enemy, not to protect alliance members against each other.” Glenn Snyder, Alliance Politics 4 (Cornell Univ. Press 2007). 
protection against all attacks regardless of their source, origin, or nature. ${ }^{48}$ Thus, although NATO was created as a western alliance against Soviet aggression in Europe and North America, the North Atlantic Treaty did not identify the Soviet Union, any of its Eastern European satellites, or any particular adversary as its principal target. ${ }^{49}$ In fact, the only instance in which a NATO ally was deemed to have been the victim of an armed attack, thereby activating Article Five of the North Atlantic Treaty, was in the aftermath of the terrorist attacks of September 11, 2001, against the United States. ${ }^{50}$ Nor do collective security mechanisms discriminate on the basis of the identity of the victim. All members of a collective security mechanism, whether large or small, strong or weak, are afforded an identical guarantee of protection. ${ }^{51}$ In short, collective security guarantees that all aggressors will be equally opposed and that all victims will be equally defended.

Collective security is predicated on a belief in the indivisibility of security among its Member States. This means that the participating states believe that their individual security is jeopardized whenever an ally is threatened or attacked, even if that threat or attack does not directly implicate or affect every

48 Thomas Weiss et al., The United Nations and Changing World Politics 26-27 (Westview Press 2001) (Underlying collective security is a single assumption: "all states would join forces to prevent one of their number from using coercion to gain advantage. Under such a system, no government could conquer another or otherwise disturb the peace for fear of retribution from all other governments. An attack on one would be treated as an attack on all.”).

49 J. Lawton Collins, NATO: Still Vital for Peace, 34 FOREIGN AFF. 367, 368-70 (1956) (emphasizing that NATO’s “military form was evolved slowly and steadily, albeit reluctantly, to meet a definite and growing Russian military threat”).

50 Suzanne Daley, After the Attacks: The Alliance; For the First Time, NATO Invokes Joint Defense Pact with U.S., N.Y. TIMES (Sept. 13, 2001), http://www.nytimes.com/2001/09/13/us/after-attacks-alliancefor-first-time-nato-invokes-joint-defense-pact-with-us.html.

51 Accordingly, agreements such as the U.S.-Japan Defense Pact does not constitute a collective security arrangement because it operates as a one-way street. Article 5 of this agreement states:

Each Party recognizes that an armed attack against either Party in the territories under the administration of Japan would be dangerous to its own peace and safety and declares that it would act to meet the common danger in accordance with its constitutional provisions and processes.

Any such armed attack and all measures taken as a result thereof shall be immediately reported to the Security Council of the United Nations in accordance with the provisions of Article 51 of the Charter. Such measures shall be terminated when the Security Council has taken the measures necessary to restore and maintain international peace and security.

Treaty of Mutual Cooperation and Security Between Japan and the United States of America, Jan. 19, 1960, 11 U.S.T. 1632.

As this provision demonstrates, this agreement limits protection to the territory of Japan. In other words, if the United States were to suffer an armed attack on its own territory or against its armed forces stationed outside Japan, this treaty would not obligate Japan to consider such an attack against the United States as an attack against Japan. Id. 
member state of a collective security mechanism. ${ }^{52}$ This requires a significant reconfiguration of a state's understanding of its national interest. ${ }^{53}$ Traditionally, states will only use force to defend their national territory or their vital national interests. ${ }^{54}$ By joining a collective security arrangement, however, states expand their definition of their national security and vital interests to include the survival and security of their allies. ${ }^{55}$ As Hans Morgenthau explains, collective security requires forsaking "national egotisms and the national policies serving them. Collective security expects policies of the individual nations to be inspired by the idea of mutual assistance and the spirit of self-sacrifice, which will not shrink even from the supreme sacrifice of war should it be required." 56

The security regime created by the U.N. Charter, the centerpiece of which is the Security Council, shares none of these features of a collective security mechanism. ${ }^{57}$ Rather, the Security Council was designed and continues to operate as a Great Power Concert. This will become apparent by examining the content and negotiating history of the provisions of the U.N. Charter that relate to the powers, prerogatives, and structure of the Security Council. Before doing so, however, it is necessary to outline the characteristics of a Great Power Concert and to highlight how this type of security regime differs from a collective security mechanism.

The Concert of Europe is the paradigmatic example of a Great Power Concert. It was a security regime that provided a mechanism for the leading European powers of the nineteenth century to consult on political matters and

52 Andrew Hurrell, Collective Security and International Order Revisited, 11 INT’L REL. 37, 47 (1992) (The members of a collective security mechanism are "prepared to see an aggression anywhere as a threat to the peace, and to view an attack against one as an attack against all. Peace, in other words, must be seen as indivisible.”).

53 SHIMKO, supra note 46, at 67. ("Because the protection of each state's security becomes the responsibility of the wider international community, states would no longer be in a pure self-help situation.”).

54 Id.

55 Id.

56 Hans Morgenthau, Politics Among Nations 415 (3d ed. 1960).

57 I use the term "security regime" to refer to the rules and institutions within the U.N. system that relate to international peace and security. While the Security Council is the principal institutional component of this security regime, it is not the only U.N. organ that is involved in questions of international peace and security. The U.N. General Assembly is empowered to adopt recommendations that relate to matters of peace and security, including questions of disarmament and arms control. Moreover, the International Court of Justice has been involved in matters of international peace and security through the exercise of both its contentious and advisory judicial functions. See Certain Expenses of the United Nations, Advisory Opinion, 1962 I.C.J. 151, at 163 (July 1962) (affirming that the Security Council's responsibility to maintain international peace and security "is 'primary,' not exclusive. .. . The Charter makes it abundantly clear, however, that the General Assembly is also concerned with international peace and security”). 
to jointly manage the affairs of the continent. ${ }^{58}$ As I discuss further below, the Concert of Europe and the United Nations emerged from similar political circumstances. Both of these bodies began as a grand military alliance in the midst of a major armed conflict and then evolved into a political apparatus to manage the post-war order. The United Nations was the military alliance led by the United States, the Soviet Union, and Great Britain against the Axis powers of World War II, ${ }^{59}$ while the Concert of Europe originated as the alliance that united the forces of Austria, Britain, Prussia, and Russia in a bid to defeat Napoleon's France. ${ }^{60}$ Moreover, just as the allies of World War II outlined their vision for the post-war order in a number of legal and political instruments, including the 1942 Declaration of the United Nations, ${ }^{61}$ the powers allied against Napoleon concluded the 1814 Treaty of Chaumont in which they reaffirmed their commitment to defeat France and to act in concert to implement "the means best adapted to guarantee to Europe, and to themselves reciprocally, the continuance of peace.”62

After Napoleon was finally defeated at Waterloo and dispatched to St. Helena, the allied powers concluded the Treaty of the Quadruple Alliance on November 20, 1815, which created the Concert of Europe. The concert was not a twentieth-century style international organization. Unlike the League of Nations, the United Nations, or the EU, the Concert of Europe had no headquarters, no secretariat, and no Secretary-General. Rather, it operated through ad hoc meetings, which were called Congresses, at which the four Great Powers-Austria, Britain, Prussia, and Russia-deliberated on a whole range of crises and situations that threatened to undermine the European order

58 See generally PAul Schroeder, The Transformation of European Politics 1763-1848 (1994) (providing an authoritative account of the history of the Concert of Europe).

59 It was decided to call the anti-Axis alliance the "United Nations" during a meeting that was held between President Roosevelt and Prime Minister Winston Churchill while the latter was bathing in a White House bathroom during an official visit to Washington. RoBert Divine, SECOND CHANCE: THE TRIUMPH OF INTERNATIONALISM IN AMERICA DURING WORLD WAR II 48 (1967).

60 Pursuant to Article I of the Treaty of Chaumont, if France refused to surrender, the allied powers committed "to apply all the means of their respective States to the vigorous prosecution of the War against that Power, and to employ them in perfect concert, in order to obtain for themselves and for Europe a General Peace.” Treaty of Union, Concert and Subsidy between Austria, Great Britain, Prussia and Russia, art. 1, Mar. 1, 1814, 1 B.F.S.P. 121 [hereinafter Treaty of Chaumont]. This treaty is widely understood to have been the precursor of the Concert of Europe. See MARK JARRETT, THE CONGRESS OF ViENNA AND ITS LEGACY 57 (I.B. Tauris 2013) (highlighting that "[t]he Treaty of Chaumont constituted a decisive step in the development of the future Congress system”).

611942 Declaration of the United Nations, UnITED NATIONS, http://www.un.org/en/sections/historyunited-nations-charter/1942-declaration-united-nations/index.html (last visited Apr. 13, 2018).

62 Treaty of Chaumont, supra note 60, art. V. 
or to upset the balance of power between these states. ${ }^{63}$ These Congresses were convened pursuant to Article VI of the Treaty of the Quadruple Alliance, which provided that:

To facilitate and to secure the execution of the present treaty, and to consolidate the connections which at the present moment so closely unite the four sovereigns for the happiness of the world, the High Contracting Parties have agreed to renew their meetings at fixed periods, either under the immediate auspices of the Sovereigns themselves or by their respective Ministers, for the purpose of consulting upon their common interests, and for the consideration of the measures which at each of these periods shall be considered the most salutary for the repose and prosperity of nations and for the maintenance of the peace of Europe. ${ }^{64}$

Putting aside the pompous poeticism of nineteenth-century diplomatic language, the outstanding feature of this provision is that, unlike Article Five of the North Atlantic Treaty quoted above, the Great Powers promised nothing in the Treaty of the Quadruple Alliance except that they shall meet regularly to consult on matters of common interest and to consider the measures deemed necessary to maintain peace and stability in Europe. ${ }^{65}$ Nowhere did these Great Powers promise to preserve the peace, nor did these powers commit to defend each other or any other state against aggression, nor did they guarantee to enforce international law or to uphold the political understandings or legal agreements reached at the Congresses that these powers held. ${ }^{66}$ The Great Powers retained the authority to determine which situations were serious enough to warrant convening a Congress, and in exercising that authority, the decision to convene a Congress almost always depended on whether a situation affected the security, interests, or rights of a Great Power. Situations that threatened the rights and interests of Europe's lesser powers simply did not necessitate convening a meeting of the Great Powers. These Great Powers also retained the discretion to determine what measures should be implemented to address these situations. Indeed, the Great Powers did not commit to consult or

63 In addition to the Congress of Vienna (1814-1815), the most important of these Congresses were: the Congress of Aix-la-Chapelle (1818), the Congress of Troppau (1820), the Congress of Laibach (1821), and the Congress of Verona (1822).

64 Richard Langhorne, Reflections on the Significance of the Congress of Vienna, 12 REV. INT'L STUD. 313, 319 (1986).

65 Tim Chapman, The Congress of Vienna: Origins, Processes and Results 16 (1998).

66 Mark Jarrett, The Congress of Vienna and its Legacy: War and Great Power Diplomacy after Napoleon 84-86 (2013). 
confer with the less influential European states. ${ }^{67}$ The Concert of Europe, in other words, was not democratic. Rather, it was "a great power directorate" to oversee European affairs. ${ }^{68}$ The right of these Great Powers to determine the fate of Europe was based on nothing but the fact of their superior material power. As Friedrich von Gentz, the Secretary of the Congress of Vienna, observed, these powers arrogated to themselves the authority to govern Europe because they were "the only ones who could destroy the system by a change of policy. The twists and turns of the others could never have this effect." 69

Despite the absence of any guarantee of collective action to preserve the peace or prevent aggression, the Concert of Europe contributed to continental peace by helping to avert Great Power war, at least until the Crimean War of 1853. Critical to the success of the Concert of Europe, especially during the early years of its operation, was the common strategic outlook shared by the leading European powers of that era. ${ }^{70}$ These states generally agreed on the principal sources of threats to order and stability in Europe and committed to consult and act in concert to confront these threats. First and foremost, having successfully defeated Napoleon's continental imperium, the Great Powers agreed on the necessity of preventing any single power from militarily or politically dominating the continent. These powers also recognized the necessity of respecting each other's vital interests, maintaining close contacts between the political leadership of the Great Powers, and conforming to the terms of the agreements and political understandings forged during their periodic Congresses. ${ }^{71}$ Moreover, for the conservative monarchies of Europe, especially Austria and Russia, cooperation was necessary to defend against the danger of domestic instability caused by reformists and radical revolutionaries alike. $^{72}$

67 Richard Elrod, The Concert of Europe: A Fresh Look at an International System, 28 WORLD POL. 159, 163 (1976) (explaining that the Concert of Europe "meant great power tutelage over the rest of Europe. It consisted only of the great powers; lesser states were occasionally consulted when their interests were involved, but they possessed few rights and certainly not that of equality”).

68 BRIDGE \& BULLEN, supra note 34, at 26.

69 F. Harry Hinsley, Power AND the Pursuit of PeACE 198 (1967).

70 Robert Jervis, From Balance to Concert: A Study in International Cooperation, 38 WoRLD POL. 58, 65 (1985).

71 Paul Schroeder, Did the Vienna Settlement Rest on a Balance of Power?, 97 AM. HIST. REV. 683, 694 (1992) (explaining that the relative peace that reigned in Europe in the decades following the Napoleonic wars was imputable to "a mutual consensus on norms and rules, respect for law, and an overall balance among the various actors in terms of rights, security, status, claims, duties, and satisfactions rather than power”).

72 Agatha Ramm, Grant and Tempreley's Europe in the Nineteenth Century 141-45 (7th ed. 1999) (noting that Austria’s Count Klemens von Metternich “argued that the Quadruple Alliance did commit its members to armed interference to suppress internal revolution in any country” and adding that "[a]fter 1820 the Congress System became in effect a trade union of Kings for suppressing the liberties of people”). 
Once the strategic outlook of the Great Powers diverged, however, the Concert of Europe became less effectual. ${ }^{73}$ The principal source of discord between the erstwhile allies related to the question of intervention in the internal affairs of states to prevent social upheavals that could threaten monarchical rule. Austria and Russia sought to use the concert to authorize and justify intervention to quell popular uprisings against European monarchies. Britain, on the other hand, viewed the concert as a mechanism to mobilize against any power seeking to achieve continental dominance by force. ${ }^{74}$ These differences became apparent when, at the 1818 Congress of Aix-la-Chapelle, Russia's Tsar Alexander II proposed transforming the Concert of Europe into an Alliance Solidaire that would have required that "all the States of Europe should mutually guarantee, not only each others' territories and possessions, but the existing form of government." 75 If implemented, this proposal would have upgraded the Concert of Europe into a collective security mechanism dedicated to preserving the territorial integrity of European states and protecting their governments against regime change. Britain's response to the Tsar's proposal deserves to be quoted here because it demonstrates clearly and succinctly the contrast between collective security and concert of powers:

There is no doubt that a breach of the covenant by any one state is an injury which all other states may, if they shall think fit, either separately or collectively resent, but the treaties do not impose, by express stipulation, the doing so as matter of positive obligation. . .. The idea of an 'Alliance Solidaire' by which each state shall be bound to support the state of succession, government, and possession within all other states from violence and attack, upon condition of receiving for itself a similar guarantee, must be understood as morally implying the previous establishment of a system of government as may secure and enforce upon all kings and nations an internal system of peace and justice. ... Till, then, a system of administering Europe by a general alliance of all its States can be reduced to some practical form, all notions of general and unqualified guarantee must be abandoned, and States must be left to rely for their security upon the justice and wisdom of their respective systems . . . ${ }^{76}$

\footnotetext{
73 The growing differences between the allies, especially between Britain and the continental states, led to the latter's withdrawal from the Quintuple in 1822 followed by France. See SYLVESTER HEMLEBEN, PLANS FOR WORLD PEACE THROUGH SiX CENTURIES 101-03 (1943).

74 Henry Kissinger, A WORLd RESTORED 5-6 (1957).

75 Harold Nicolson, The Congress of Vienna: A Study in Allied Unity 1812-1822 264-65 (1946).

76 René Albrecht-CARrié, The ConCERT OF Europe 37, 42 (1968).
} 
In effect, what the British Government was saying is that, first, the Quadruple Alliance did not entail any guarantee of mutual assistance and did not generate any legal obligation on its members to aid their partners or protect them against an attack on their governments, possessions, or territories. ${ }^{77}$ Second, Britain argued that in the event of a breach of international law, each member of the Great Powers retains discretion to determine whether the situation necessitates a collective response. ${ }^{78}$ Therefore, Britain concluded, "all notions of general and unqualified guarantee must be abandoned," and each state must be left to fend for itself. ${ }^{79}$

As the next section demonstrates, the U.N. security regime, the core of which is the Security Council, operates on the bases of a similar set of assumptions. ${ }^{80}$ The composition, structure, and powers of the Security Council bear a striking resemblance to the Concert of Europe. Both of these bodies created a Great Power directorate to oversee and manage the European statesystem, in the case of the Concert of Europe, and the international system, in the case of the Security Council. Moreover, neither of these bodies provided its members any guarantee of protection against aggression or any promise to enforce international law. And finally, the Great Powers that led both of these bodies retained limitless discretion regarding whether and how to respond to breaches of international law and whether and how to intervene in crises that threatened peace and security.

77 Id. at 37.

78 Id. at 42.

79 Id.

80 One possible critique of the claims I make in the Essay is that I have adopted an unnecessarily narrow definition of the concept of collective security. It might be said that collective security is a protean concept that admits various forms of security regimes, including security regimes and arrangements that operate on the bases of rules and assumptions that are less exacting than those I outlined in this Section. Accordingly, it could be argued that I have constructed an artificial threshold that is too high for the Security Council to realistically meet. In short, I would be accused of creating a vulnerable strawman. I disagree with such criticism. If "collective security" is to mean anything, its features would have to be distinguishable from other security regimes, such as concerts, alliances, or balances of power. As Richard Betts explains, defining collective security less restrictively:

[b]y making it less collective and less automatic [makes it] hard to differentiate from the traditional balance of power standards it is supposed to replace. Unless collective security does mean something significantly different from traditional forms of combination by states against common enemies, in alliances based on specific interests, the term confuses the actual choices .... [If] collective security is qualified to allow exceptions to the general rule according to caseby-case judgment on the merits of interests and claims, the distinction of the concept from a regular alliance becomes hopelessly blurred.

Richard Betts, Systems for Peace or Causes of War? Collective Security, Arms Control, and the New Europe, 17 INT'L SEC. 5, 8-10 (1992). 


\section{The Origins And Policy Purposes of the U.N. SECURITY REgime}

The U.N. security regime is composed of a set of rules and institutions. These rules are codified in the U.N. Charter, which also outlines the mandates of the institutions that constitute this security regime. ${ }^{81}$ Before describing the content of these rules and the powers of these institutions, however, it is necessary to identify the policy purposes underlying these rules and institutions. This is because rules and institutions are not natural phenomena. They are human creations that are designed to serve the political, economic, and social interests of their creators. Indeed, the content of all rules and the structure of the institutions entrusted with the application of these rules are determined by these interests. ${ }^{82}$ Accordingly, to understand why the U.N. security regime was designed the way it was, and to appreciate why the Security Council is structured in the way it is and why it operates the way it does, it is necessary to identify the policy purposes that this security regime was intended to serve.

The U.N. security regime is a child of its times. Just as Austria, Britain, Russia, and Prussia created the post-Napoleonic European order at the Congress of Vienna, the United States, the Soviet Union, and Britain convened a series of summit conferences and meetings during which the parameters of the post-World War II world order the structure of the United Nations were determined. ${ }^{83}$ The most significant of these summits and meetings were the Dumbarton Oaks Conference and the Yalta Conference. ${ }^{84}$ Having endured two World Wars, the founding fathers of the United Nations sought, above all else,

81 U.N. Charter, Chapter V; see also Kenneth Manusama, The United Nations Security CounCIL IN THE POST-COLD WAR ERA 47-62 (Martinus Nijhoff 2006).

82 As Michael Reisman notes: "It is a truism that all law is policy, in the sense that every legal argument, however humble, procedural, or 'technical' it may seem, has been designed in order to achieve some preferred social or economic objective.” MichaEL REISMAN, THE QUEST OF WORLD ORDER AND HUMAN Dignity in the Twenty-First Century: Constitutive Process AND Individual Commitment 28-29 (2010).

83 Stephen Schlesinger, Act of Creation: The Founding of the United Nations 1, 1-16 (Westview Press 2003).

84 See generally Robert Hilderbrand, Dumbarton OAKs: The Origins of the United Nations AND the SEARCh for Postwar Security (Univ. North Carolina Press 1990); S.M. Plokhy, Yalta: The PRICE OF PEACE (Viking Penguine 2010). The agreements reached by the Great Powers at Dumbarton Oaks and later during the Yalta Conference were largely unaltered during the San Francisco Conference during which the U.N. Charter was drafted and adopted. See Charles Webster, The Making of the Charter of the United Nations, 32 History 16, 33 (1947) (noting that "though some important additions were made, the Dumbarton Oaks Proposals were in all essentials accepted, and not one of the fifty states represented [at the San Francisco Conference] refused to sign or ratify the Charter”). 
to prevent World War III. ${ }^{85}$ This, in their view, required providing a mechanism that would help maintain peace between the Great Powers, which were the only states capable of threatening world order due to their global political influence and unparalleled military capabilities. It was also assumed that, by virtue of their superior capabilities, the responsibility of managing the international system and confronting threats to world order would fall to those Great Powers. President Roosevelt even envisioned the Great Powers as "Four Policemen" who would oversee world politics and cooperate to confront threats to world peace. ${ }^{86}$ Therefore, for the creators of the post-World War II order, "the cornerstone of world security is the unity of those nations which formed the core of the grand alliance against the Axis." 87 If those powers worked together effectively in responding to international crises, the United Nations would succeed and peace would prevail. It was hoped that the United Nations would provide a forum that would enable those Great Powers to remain united, to coordinate their policies, and to co-manage the international system.

One important factor that influenced the United States, Soviet, and British leaders who deliberated on and determined the structure and functions of the United Nations was the lessons learned from the failure of the League of Nations. ${ }^{88}$ In particular, it was recognized that the League had been ineffectual because the most powerful states in the international system had either never joined the League, as in the case of the United States, ${ }^{89}$ or were expelled from it, as in the case of the Soviet Union. ${ }^{90}$ Therefore, it was agreed that the success of the United Nations and the future of world order depended on

85 Edward Luck, UN Security Council: Practice AND Promise 34 (2006) (describing the "founding goal” of the United Nations as "avoiding a third world war").

86 George Schild, The Roosevelt Administration and the United Nations: Recreation or Rejection of the League Experiment?, 158 WorlD AFF. 26, 29 (1995). The establishment of the United Nations was spearheaded by three powers: the United States, the Soviet Union, and Britain. As this process evolved, the United States succeeded in involving China in the creation of the United Nations. It was those four powers that were imagined as the Four Policemen. Later, after its liberation from Nazi occupation, France was included in the creation of the United Nations and given a permanent seat on the U.N. Security Council. See STEPHEN Schlesinger, Act of Creation: The Founding of the United Nations 33-53 (Westview Press 2003).

87 James Sutterlin, The Past as Prologue, in The Once AND Future of THE SECuRITy CounciL 3 (Bruce Russet ed., 1997).

88 Webster, supra note 84, at 17 (“The twenty years' experience of the League of Nations had by far the most important influence on the making of the Charter.”).

89 For a thorough recounting of the debates within the United States on the question of ratifying the Covenant of the League of Nations, see generally John Milton Cooper, Breaking the HeART OF THE World: WoOdROW WiLSON AND THE Fight FOR THE LEAGUE OF NATIONS (Cambridge Univ. Press 2001).

90 Leo Gross, Was the Soviet Union Expelled from the League of Nations?, 39 AM. J. INT'L L. 35,35 (1945). 
ensuring that the Great Powers joined, remained in, and participated in the operations of the United Nations. ${ }^{91}$ To incentivize them to join the United Nations, the Great Powers needed assurances that their security and vital interests would not be jeopardized by the new organization. Otherwise, these powers might decline to join the organization and might adopt a hostile attitude towards it.

These were the basic policy purposes and assumptions that guided the creation the U.N. security regime and determined the content of its rules and the structure of its institutions. It was understood that the U.N. security regime would be centered on an institution with limited membership (i.e., the Security Council) which would be made responsible for matters of war and peace. Second, it was agreed that this institution would be empowered with vast enforcement powers, including the ability to authorize the use of force in response to threats to the peace. Third, it was decided that the Great Powers would enjoy special privileges within that institution. These privileges were given in light of the special responsibilities of these leading states in the international system and as an assurance against the possibility that the United Nations would threaten the security or vital interests of these Great Powers.

\section{The Powers, Prerogatives, AND Structure of the U.N. Security COUNCIL}

Obviously, to discuss every attribute of the U.N. security regime and every feature of its institutional structure would require a treatise-length tome, which is not possible here. Indeed, there are numerous issues that I will not deal with here that deserve an extended discussion and that have been the subject of a large body of scholarship. ${ }^{92}$ Rather, I will focus here on those characteristics of the Security Council that demonstrate the main claim of this Essay-namely,

91 Vaughan Lowe et al., Introduction, in The UnITEd NATIONS SECURITY CounCIL AND WAR 12 (Vaughan Lowe et al. eds., 2008) ("The Charter as a whole was drawn with the central aim of ensuring that the major powers would be willing to join, and remain in, the organization.”).

92 One of these issues is whether the Security Council is bound by international law and whether it is required to solve the crises brought before it in accordance with international law. My view on this matter, which I will be unable to explain at length here, is that the Security Council itself is not bound by international law because, I believe, the Security Council as an entity does not enjoy international legal personality that enables it to bear either rights or duties under international law nor does it have the capacity to make claims under international law. On the other hand, the United Nations as an entity and the Member States of the Security Council obviously have international legal personality and are bound to operate within the bounds of international law. Another matter that I will not be able to discuss here is the relationship between the Security Council and the other U.N. organs, especially the General Assembly and the International Court of Justice, and specifically whether the latter may exercise judicial review of the Security Council's actions, and whether the former can consider and recommend action in relation to crises on the Council's agenda. 
that the Council was intended to operate, not as a collective security mechanism, but as a Great Power concert, the principal purpose of which is to prevent Great Power war and to facilitate peaceful relations between the Great Powers.

As discussed above, the principal feature of a collective security mechanism is that it provides its members with a guarantee of protection against aggression. Nowhere, however, does the U.N. Charter extend to the U.N. Member States such a guarantee. Nor does the Charter provide any assurance of collective action to protect the political independence, territorial integrity, or security of the organization's Member States. In other words, conspicuously absent from the Charter is any language akin to that of Article Five of the North Atlantic Treaty pursuant to which the NATO members pledge to consider that an attack against one is an attack against all. Rather, the Charter merely instructs states to "settle their international disputes by peaceful means" 93 and commands them to "refrain in their international relations from the threat or use of force against the territorial integrity or political independence of any state." 94 Beyond recognizing the inherent right of states to use force to defend themselves against armed attacks, ${ }^{95}$ the Charter provides no promise of collective responses against threats or uses of force or acts of aggression.

Although the substantive rules enshrined in the Charter lack the elements of collective security, the vast powers and prerogatives of the Security Council might lead some to assume that it was intended to operate as a collective security mechanism. The Security Council is charged with the "primary responsibility for the maintenance of international peace and security." 96 To discharge this responsibility, the Council is permitted, under Chapter VI of the Charter, to recommend measures for the peaceful settlement of disputes, and is granted, pursuant to Chapter VII, the authority to order enforcement measures in response to situations that it deems to constitute a "threat to the peace, breach of the peace, or act of aggression." ${ }^{97}$ In other words, to authorize enforcement measures, the Council must first determine that the situation that it is examining amounts to a "threat to the peace," "breach of the peace," or "act of aggression." The enforcement measures available to the Council include non-forcible measures, such as economic sanctions, trade and travel

\footnotetext{
93 U.N. Charter art. 2(3).

94 U.N. Charter art. 2(4).

95 U.N. Charter art. 51.

96 U.N. Charter art. 24(1).

97 U.N. Charter art. 39.
} 
embargoes, and the severance of diplomatic ties. If these measures prove ineffectual, the Council may authorize the use of force. ${ }^{98}$ Furthermore, the U.N. Charter made decisions of the Security Council binding on all U.N. Member States, ${ }^{99}$ and decreed that obligations under the Charter shall supersede other treaty obligations, ${ }^{100}$ and even required non-U.N. Member States to cooperate in the execution of Security Council action taken to protect international peace and security. ${ }^{101}$

Nonetheless, nowhere in the provisions of the Charter that relate to the powers of the Security Council is there any obligation on the Council to intervene to preempt or resist a threat to or breach of the peace, or to protect the victims of aggression. The Great Powers that authored the Charter ensured that it would not include any language that would require the U.N. Member States to consider an act of aggression or an attack against one as an act of aggression or attack against all. Moreover, these Great Powers ensured that, even if it was determined that an act of aggression had occurred against a member state, there would be no legal obligation on the Security Council to use force to defend the victim of aggression - or, indeed, to take any action at all. Furthermore, the Great Powers were granted limitless and unreviewable discretion, through the so-called "veto power," 102 to block any proposed Security Council action that they considered would threaten or undermine their security or interests. ${ }^{103}$ Accordingly, like the Concert of Europe, what the founders of the United Nations established was not a collective security

98 This power that was granted to the Security Council to authorize the use of force in response to a threat or breach of the peace or act of aggression is unprecedented in international relations. See Niels Blokker, The Security Council and the Use of Force: On Recent Practice, in THE SECURITY COUNCIL AND THE USE OF Force: Theory AND ReAlity - A NeED FOR ChAnge? 8 (Niels Blokker \& Nico Schrijver eds., 2005) (highlighting that "a use-of-force monopoly was given to a newly created institution with powers of its own, as part of a new world organization, through a multilateral treaty. This is a fundamental difference”).

99 U.N. Charter art. 25.

100 U.N. Charter art. 103.

101 U.N. Charter art. 2(6). Given that virtually all states have joined the United Nations, the question of whether the Charter generates legal obligations for non-member states has become moot. Nonetheless, the fact that the founders of the United Nations included this provision in the Charter illustrates the unprecedented power vested in the Security Council. See Wolfgang Graf Vitzthum, Article 2(6), in THE CHARTER OF THE United NATiOns: A COMMENTARY 138 (Bruno Simma et al. eds., 1994).

102 The term "veto" is not used anywhere in the Charter. The veto, or the power of the five Permanent Members to block Security Council resolutions, is implied in Article 27(3), which states that decisions on nonprocedural matters can only be adopted with nine votes including the "concurring voters of the permanent members.” U.N. Charter art. 27.

103 One notable limitation on the veto power is that if the Security Council is exercising its powers under Chapter VI of the Charter, which relates to the pacific settlement of disputes, the parties to a dispute, including Permanent Members, are required to abstain from the vote on proposed Security Council actions under Chapter VI. See U.N. Charter art. 27(3). 
mechanism, but a "condominium of the victorious major Allies, who would jointly keep the rest in order.” 104

This becomes readily apparent from the travaux préparatoires of the Charter. At Dumbarton Oaks, the Great Powers decided to create a Council that would enjoy a "very great freedom . . . in determining what action, if any, to take" against threats or breaches to the peace or acts of aggression. ${ }^{105}$ When the draft of the Charter prepared by the Great Powers was presented at the United Nations Conference on International Organization during which the Charter was finalized and adopted, ${ }^{106}$ the delegations representing the smaller states of the world attempted to turn the Security Council into a collective security body. "Having suffered so much over the course of the war, many smaller states were looking for security assurances, if not guarantees, by urging definitions and guidelines that would push the major powers to act when their smaller neighbors were threatened." ${ }^{107}$ To do so, many delegations proposed amendments to the draft Charter prepared at Dumbarton Oaks to include an obligation on the Security Council to intervene if their rights, security, or sovereignty were threatened or attacked. The Great Powers, however, opposed all attempts to transform the Security Council into a collective security mechanism.

One such amendment, which was widely supported by the participating delegations, was advanced by Bolivia. It proposed "a list of eventualities in which intervention by the Council would be automatic." ${ }^{108}$ These included: (1) "Invasion of another state's territory by armed forces[,]" (2) "Declaration of war[,]" (3) "Attack by land, sea, or air forces, with or without declaration of war, on another state's territory, shipping or aircraft[,]" (4) "Support given to armed bands for the purpose of invasion[,]" (5) "Intervention in another state's internal or foreign affairs[,]" (6) "Refusal to submit the matter which has caused a dispute to the peaceful means provided for its settlement[,]" and (7) "Refusal to comply with a judicial decision lawfully pronounced by an

104 Michael Howard, The Historical Development of the UN's Role in International Security, in UNITED NATIONS, DividED WORLD 65 (Adam Roberts \& Benedict Kingsbury eds., 1993).

105 United Nations Conference on International Organization, Verbatim Minutes of the First Meeting of Commission III, U.N. Doc. 943, III/5, at 16 (June 13, 1945).

106 The conference was held from April 25 to June 26, 1945, in San Francisco. 1945: The San Francisco Conference, UNITED NATIONS, http://www.un.org/en/sections/history-united-nations-charter/1945-sanfrancisco-conference/index.html (last visited Apr. 13, 2018).

107 Edward Luck, A Council for All Seasons: The Creation of the Security Council and Its Relevance Today, in THE United NATiOns SECURITy CounCIL AND WAR 69 (Vaughan Lowe et al. eds., 2008).

108 Hans Kelsen, The LaW of The United Nations 729 (1964). 
international court.” 109 Building on that final element of Bolivia's proposal, another amendment was suggested that would have required the Security Council to enforce the judgments of the International Court of Justice. ${ }^{110}$

Both of these proposals, and other suggestions that would have required the Security Council to automatically intervene in certain circumstances, were rejected by the Great Powers. It was argued that these proposals would have restricted "the Council's freedom of action," 111 or, one might have added, its freedom of inaction. Moreover, it was argued that listing a specific set of situations in which Council intervention was required could be underinclusive, thereby detracting attention from other crises that could be more threatening, but that received lesser attention because they were not explicitly referred to in the Charter. It was also suggested that requiring the Council to use force in response to certain situations might lead to the premature use of force. $^{112}$

Perhaps sensing that the Bolivian proposal was too ambitious due to the wide range of contingencies it referred to, some delegations suggested requiring Security Council action in what was, and remains, the most widely recognized source of global insecurity: acts of aggression. To do so, some states proposed formulating a provision in the Charter that would have guaranteed collective action by the United Nations to resist aggression and protect the political independence and territorial integrity of states. Alternatively, some states attempted to include in the Charter a definition of aggression. This, it was assumed, would be a "means of making sure that, at least in certain defined circumstances, the 'finding' of aggression would be automatic and the Council would be required to apply sanctions." 113 Both of these proposals failed. First, aggression could not be defined conclusively and exhaustively, a problem that continues to bedevil international law. ${ }^{114}$ More importantly, the Great Powers explained that the Security Council was

\footnotetext{
109 Ruth Russell, A History of the United Nations Charter 670-71 (1958).

110 United Nations Conference on International Organization, Verbatim Minutes of the Fourth Meeting of Commission III, U.N. Doc. 1149, III/11, at 13 (June 22, 1945).

111 United Nations Conference on International Organization, Verbatim Minutes of the First Meeting of Commission III, Doc. 943, III/5, at 5 (June 13, 1945).

112 Id. at 6.

113 RuSSELL, supra note 109, at 670.

114 See Martti Koskenniemi, 'The Lady Doth Protest Too Much' - Kosovo, and the Turn to Ethics in International Law, 65 MoD. L. REV. 159, 168 (2002) (U.N. General Assembly Resolution 3314 (December 14, 1974), which sought to define aggression, included a provision that allowed the Security Council to determine that acts not enumerated in the resolution also amounted to aggression. Therefore, Koskenniemi argues, "[a]n exercise whose very point was to limit Security Council discretion ended up in defining as aggression whatever the Council chooses to regard as such!”).
} 
intended to enjoy maximum flexibility in determining whether a situation threatened international peace and security, and that it was also intended to enjoy an equal measure of flexibility to determine whether a situation that is deemed threatening to international peace and security actually warranted intervention by the Security Council. ${ }^{115}$

This limitless discretion of the Council aroused the concerns of the smaller states. As the Norwegian representative observed, the Security Council was free to propose any solution to a conflict or intervene in any manner, even if that entailed undermining the interests, security, or welfare of a U.N. member state. Therefore, it was proposed that "rules of conduct" be articulated to guide the Council's actions. ${ }^{116}$ Moreover, an amendment was proposed that would have limited the Council's choice of enforcement measures by including a provision in the Charter stating:

the Security Council should refrain from making decisions that might affect the territorial integrity and political independence of state members of the Organization. Controversies on matters of this nature should be referred to the General Assembly, either by the initiative of the Security Council or at the request of any party to the dispute. ${ }^{117}$

Both of these proposals failed. The Great Powers were adamant that nothing should be added to the Charter that would limit the Council's powers or discretion. The Charter was, therefore, adopted without any guarantee of automatic protection against aggression, and it did not include a definition of those acts that would constitute threats to or breaches of the peace or acts of aggression. ${ }^{118}$ This purposeful omission was intended so as to "leave to the Council the entire decision, and also the entire responsibility for that decision, as to what constitutes a threat to peace, breach of the peace, or an act of aggression." 119 Accordingly, the Security Council has boundless discretion in the exercise of its powers under Article 39 of the Charter to determine whether a situation constitutes a threat to the peace, breach of the peace, or act of

\footnotetext{
115 RuSSELL, supra note 109, at 673-75.

116 United Nations Conference on International Organization, Summary Report of the Thirteenth Meeting of Committee III/1, U.N. Doc. 555, III/1/27, at 4 (May 24, 1945).

117 United Nations Conference on International Organization, Continuation of the Report of the Activities of Committee III/1 Concerning Sections A, B, C, and D of Chapter VI of the Dumbarton Oaks Proposals, U.N. Doc. WD 313, III/1/51, at 3 (June 14, 1945).

118 Contra Nigel White, On the Brink of Lawlessness: The State of Collective Security Law, 13 IND. INT’L \& COMP. L. REV. 237, 238 (2002-2003) (noting that “[t]he amount of discretion is, however, is debated, with there being strong contentions that even determination of threats to the peace by the Security Council are subject to law").

119 United Nations Conference on International Organization, Verbatim Minutes of the First Meeting of Commission III, U.N. Doc. 943, III/5, at 6 (June 13, 1945) (emphasis added).
} 
aggression. ${ }^{120}$ Such a situation need not constitute an unlawful act under international law, and, conversely, nothing in the Charter requires the Council to determine that a breach of international law-including acts of aggressionconstitutes threats to or breaches of the peace. ${ }^{121}$

Even if it declares that a situation does indeed threaten the peace or amount to a breach of the peace or act of aggression, the Security Council is under no obligation to take any measures to resist, respond to, or address that situation. ${ }^{122}$ As Hans Kelsen put it succinctly, the Security Council "is under no obligation to take enforcement measures after it has determined the existence of a threat to, or breach of, the peace." ${ }^{123}$ Assuming it actually decides to take enforcement measures, the Charter places little, if any, limits on the Security Council's authority to determine which measures are necessary and appropriate. This authority includes the power to order measures that would ordinarily constitute violations of treaty law and rules of customary international law. ${ }^{124}$ Indeed, a careful reading of Article 1(1) of the Charter indicates that while the United Nations is required to comply with the "principles of justice and international law" when settling disputes by peaceful means, no such requirement or limitation is placed on the United Nations when using non-peaceful means, such as Security Council enforcement measures, to address an international crisis. ${ }^{125}$

120 Benedetto Conforti \& Carlo Focarelli, The LAw And Practice of the United Nations 226 (4th ed. 2010) (noting that "in fact the Security Council may duly take account of any conduct of a State, considering it to be a threat to the peace a breach of the peace or an act of aggression ... regardless of whether it might be lawful or not”).

121 KELSEN, supra note 108, at 730 (While threats or uses of force constitute a violation of Article 2(4) of the Charter, "the Security Council may decide that such conduct is neither a threat to the peace nor a breach of the peace, and consequently the Council is not entitled to take enforcement measures.”).

122 Michael Byres, War Law: International LAW AND ARMEd Conflict 16 (2005) ("The Council has an equally broad authority to decide which measures shall be taken to 'maintain or restore international peace and security."”).

123 KeLSEN, supra note 108, at 734.

124 ERIKA DE Wet, The Chapter VII Powers of the United NATIONS SECURITy CounCil 182 (2004) (The Council has "a wide discretion to deviate from customary international law or treaty law when resorting to enforcement measures.”). Whether the Security Council is bound to respect jus cogens is another matter on which scholarly opinion is unsettled. For this author, the Security Council is essentially unbound by law, including jus cogens. Fully expounding this view, however, is best left for future research. But see Dapo Akande, The International Court of Justice and the Security Council: Is There Room for Judicial Control of Decisions of the Political Organs of the United Nations?, 46 INT'L \& COMP. L. Q. 309, 322 (1997), for an opposing view.

125 U.N. Charter art. 1(1) states that the Purposes of the United Nations are:

To maintain international peace and security, and to that end: to take effective collective measures for the prevention and removal of threats to the peace, and for the suppression of acts of aggression or other breaches of the peace, and to bring about by peaceful means, and in 
Despite the controversial nature of the breadth of the Security Council's powers and discretion, "the most serious crisis of the [San Francisco] Conference on International Organization arose over the so-called veto power of the permanent members." ${ }^{126}$ The veto is codified in Article 27 of the U.N. Charter. It stipulates that proposed Security Council decisions on nonprocedural matters cannot be adopted if any of the five Permanent Members vote against it. Therefore, one of the most contentious issues during the negotiations at San Francisco was the definition of "procedural matters." If, as the delegate of Australia explained, the "phrase 'procedural matters' is defined narrowly, the veto power of each permanent member is correspondingly widened. If 'procedural matters' is given a wider and more liberal definition, the veto power of each permanent member is correspondingly narrowed." 127 Therefore, in an attempt to constrain the veto, an amendment was proposed to categorize all resolutions on the peaceful settlement of disputes as procedural matters. ${ }^{128}$ In response to this proposed amendment, the Great Powers that drafted the original Dumbarton Oaks proposals issued a joint statement defining those "procedural matters" that would not be subject to the veto. This statement provided an illustrative list of procedural matters, which included: adopting the Council's rules of procedure, selecting the times and places of the Council's meetings, inviting Member States to attend the Council's sessions, and inviting parties to a dispute to participate in discussions on the matter in the Council. The statement also indicated that the Permanent Members would not use the veto to deny states the right to bring a dispute to the Council's attention and that Permanent Members could not prevent a matter from being discussed and considered by the Council. The statement then drew the critical dividing line between procedural and substantive matters. In a paragraph that reveals the reality of the Security Council as a Great Power concert, the statement read:

conformity with the principles of justice and international law, adjustment or settlement of international disputes or situations which might lead to a breach of the peace[.]

U.N. Charter art. 1(1). But see Daniel Joyner, The Security Council as a Legal Hegemon, 43 GEO. J. INT’L L. 225, 234 (2012) (arguing that "the Charter does provide limits upon the discretion of the Council in its exercise of its powers. As the Council derives its powers from the Charter's terms, it is by the same process bound by the constraints and limitations of those terms"); Simon Chesterman, The UN Security Council and the Rule of Law, Final Report and Recommendations of the Austrian Initiative, 2004-2008, at 10 ("It is generally acknowledged that the Security Council's powers are subject to the UN Charter and norms of jus cogens.”).

126 Dwight Lee, The Genesis of the Veto, 1 INT’L ORG. 33, 37 (1947).

127 United Nations Conference on International Organization, Verbatim Minutes of the Fourth Meeting of Commission III, U.N. Doc. 1149, III/11, at 20 (June 22, 1945).

128 United Nations Conference on International Organization, Summary Report of Nineteenth Meeting of Committee III/1, U.N. Doc. 956, III/1/47, at 6-7 (June 13, 1945). 
Beyond this point [of bringing a dispute to the Council's attention], decisions and actions by the Security Council may well have major political consequences and may even initiate a chain of events which might, in the end, require the Council under its responsibilities to invoke measures of enforcement . . . . This chain of events begins when the Council decides to make an investigation, or determines that the time has come to call upon states to settle their differences, or makes recommendations to the parties. It is to such decisions and actions that unanimity of the permanent members applies, with the important proviso, referred to above, for abstention from voting by parties to a dispute. ${ }^{129}$

In effect, what this statement made clear is that the only decision of any political consequence that would not be subject to the veto is "whether a dispute ought to be fully discussed. It can only investigate whether a dispute ought to be fully investigated." 130 In other words, the U.N. Member States were only guaranteed a right to bring a dispute or crisis to the attention of the Security Council and to call upon it to intervene. Beyond that, the Permanent Members retained the right to veto any finding that a situation constituted a threat to international peace and security and had an equally broad right to veto any proposed action by the Security Council to respond to international crises or conflicts. The theory, as the Great Powers argued in their joint statement, was that without the veto a "chain of events" might be unleashed that might ultimately lead to Great Power war, which was exactly what the United Nations was established to avoid.

When delegations sought assurances that the veto would not be used "unthinkably or unjustly or tyrannically," ${ }^{131}$ the U.S. representative noted that "it was impossible to give an exact interpretation which would foresee all future contingencies. The final responsibility as to the interpretation would rest with each individual delegate when he cast his vote on the basis of his own judgment and all available information." ${ }^{132}$ In other words, the Great Powers that were to be granted Permanent Membership on the Council would exercise

129 United Nations Conference on International Organization, Statement by Mr. John Sofianopoulos, Chairman of Technical Committee III/1 on the Structure and Procedures of the Security Council, U.N. Doc. 852, III/1/37(1) Annex to U.N. Doc. 1050, III/1/58, at 2 (June 8, 1945).

130 United Nations Conference on International Organization, Verbatim Minutes of the Fourth Meeting of Commission III, U.N. Doc. 1149, III/11, at 23 (June 22, 1945).

131 United Nations Conference on International Organization, Verbatim Minutes of the Fifth Meeting of Commission III, U.N. Doc. 1150, III/12, at 19 (June 22, 1945).

132 United Nations Conference on International Organization, Summary Report of Sixteenth Meeting of Committee III/1, U.N. Doc. 897, III/1/42, at 4 (June 10, 1945). 
the veto as they saw fit. There would be no legal restraints, constraints, or limits to their discretion.

The representatives of the smaller countries immediately realized the consequences of the breadth of the Security Council's powers and the privileges enjoyed by the Permanent Members. The lack of any obligation to protect the U.N. Member States against aggression combined with this voting scheme meant that it was "impossible for the Security Council to determine the existence of a threat to the peace or act of aggression by one of the Permanent Members." 133 Indeed, in an irony of history, Syria, which is currently being portrayed as another example of the failure of the Security Council, provided a preview of the practical implications of the veto even before the Charter was adopted. During the San Francisco Conference, France executed a brutal intervention in Syria to quell an uprising that was demanding independence from France, which included aerial bombardment of Syrian cities, including Damascus, and which caused mass civilian casualties. ${ }^{134}$ Referring to this ongoing aggression, the Egyptian delegate warned that "France would have been able to exercise her right of veto, had the Security Council been in existence and had France occupied a permanent seat. France could have prevented the application of any enforcement measures to stop this action.”135

Moreover, because the Permanent Members enjoy discretion in defining their vital interests, it was recognized that these states could freely extend the immunity against Security Council action afforded to them to their allies. ${ }^{136}$ Accordingly, when the United States vetoes resolutions that direct even the faintest censure at Israel for its continued occupation of the Palestinian territories or when Russia or China protect their Syrian or Iranian allies against Western-authored Security Council resolutions, these Great Powers are acting well within their rights.

That was the offer-indeed, the non-negotiable offer-presented by the Great Powers to the world during the San Francisco Conference. The veto was

133 United Nations Conference on International Organization, Committee III/1, Statement of the Delegate of the Netherlands at Ninth Meeting, U.N. Doc. WD. 215, III/1/36, at 4 (June 7, 1945).

134 Christopher O'Sullivan, FDR and the End of Empire: The Origins of American Power in the Middle East 145 (Palgrave Macmillan 2012).

135 United Nations Conference on International Organization, Verbatim Minutes of the Fourth Meeting of Commission III, U.N. Doc. 1149, III/11, at 8 (June 22, 1945).

136 Writing in 1946, a member of the U.S. delegation to the San Francisco Conference noted that "[n]o great power can be the object of enforcement action, and it is likely that a great power would use its veto to prevent action from being taken against one of its satellites.” Grayson Kirk, The Enforcement of Security, 55 YALE L.J. 1081, 1095 (1946). 
a conditio sine qua non for the Great Powers; they would not join the United Nations without the assurance that the organization would not be used to undermine to threaten their security or vital interests. ${ }^{137}$ Despite deep misgivings and widespread resentment towards the veto, it was adopted as devised by the Great Powers. ${ }^{138}$

The reality of the Security Council should now be apparent. It is not an enforcer of international law nor is it a collective security mechanism that provides a legally guaranteed assurance of aid and protection in the event of aggression. Rather, the Security Council is a concert of Great Powers, not unlike the Concert of Europe of the nineteenth century. It provides a forum intended to facilitate the maintenance of peaceful relations between the Great Powers and to enable those states to co-manage the international system. ${ }^{139}$

The result of this institutional design and the privileges granted to the Permanent Members were over seven decades of "selective security."140 Rarely, such as in response to Iraq's invasion of Kuwait, the Security Council acted swiftly, forcefully, and effectively. ${ }^{141}$ More frequently, however, the Council opted not to act. The reasons for inaction vary depending on the circumstances. The most obvious reason for inaction are the 202 vetoes cast by the Permanent Members as of March 1, 2018. ${ }^{142}$ The veto, or the threat of the veto, meant that the Security Council was helpless whenever a Permanent

137 During the negotiations, U.S. Senator Tom Connally made it abundantly clear that the veto was nonnegotiable. He suggested that if the smaller powers killed the veto, they would also kill the Charter by rhetorically asking whether "delegates could face public opinion at home if they reported that they had killed the veto but had also killed the Charter.” United Nations Conference on International Organization, Summary Report of Nineteenth Meeting of Committee III/1, U.N. Doc. 956, III/1/47, at 8 (June 13, 1945).

138 As the delegate of Egypt noted, "The great powers had made it plain that the veto was essential; the smaller powers, perhaps 40 out of the 50 delegations, were opposed to it.” Id. at 6 .

139 This conclusion is not meant to suggest that international law has no impact on the Security Council. Deliberations within the Security Council occur in the shadow of the law. The Permanent Members and NonPermanent Members on the Council use the language of international law to justify their positions to their fellow Council-members, to the broader U.N. membership, and to global public opinion. This process of justification inevitably affects the policies of states. See Ian Johnstone, Security Council Deliberations: The Power of the Better Argument, 14 EURO. J. INT'L L. 437, 440-43 (2003). Nevertheless, while recognizing that international law does affect the outcomes of Security Council deliberations, it is important not to lose sight of the fact that the Council is not a global law enforcer, that it retains limitless discretion regarding whether and how to respond to threats to or breaches of the peace, and that the Permanent Members enjoy limitless discretion regarding the use of the veto.

140 AdAm Roberts \& DOMiniK ZAUM, SELECTIVE SECURITY: WAR AND THE UNITED NATIONS SECURITY Council SinCE 1945 74-77 (Adelphi Paper 2008).

141 Mary Ellen O’Connell, Enforcing the Prohibition on the Use of Force: The U.N.'s Response to Iraq's Invasion of Kuwait, 15 S. ILL. U. L.J. 453, 453 (1991).

142 A list of all draft Security Council resolutions that were vetoed is available here: Meeting Records, U.N. SEC. COUNCIL, http://www.un.org/en/sc/meetings/records/2017.shtml (last visited Apr. 13, 2018). 
Member committed an act of aggression or intervened in a foreign state, such as the Franco-British-Israeli aggression against Egypt, otherwise known as the Suez Crisis (1956); the Soviet interventions in Hungary (1956), Czechoslovakia (1968) and Afghanistan (1979); or the U.S. interventions against Cuba (1961), Grenada (1983), Panama (1989), and Iraq (2013). Even if a Permanent Member did not directly commit an act of aggression, the Security Council was prevented from addressing crises or conflicts that affected the interests of those states or that occurred within those states' spheres of influence. The Security Council was also often prevented from intervening whenever a Permanent Member protected an ally or client state. In addition to instances of Security Council paralysis due to disagreements between its Permanent Members, there were moments of non-intervention because the Permanent Members had an interest in the continuation of an armed conflict. During the eight-year Iran-Iraq war, which was the longest war of the twentieth century, the Permanent Members "spent much of the war supplying arms, material, dual-use items and financial credits to one or other of the belligerents, and sometimes to both, helping the war efforts of both countries." ${ }^{143}$ On other occasions, the Security Council failed to intervene due to the indifference of the Permanent Members, such as the 1994 Rwandan Genocide during which 800,000 lives were lost. ${ }^{144}$

Great Power politics and the veto were not the sole determinants of whether the Security Council decided to intervene, nor were they the only variables that determined whether intervention was successful. In some cases, U.N. Member States were recalcitrant to provide the necessary support to ensure the success of U.N. interventions. Especially in the context of the multidimensional peacekeeping operations of the post-Cold War era, ${ }^{145}$ Security Council interventions failed or were ineffectual because Member States hesitated to contribute troops to U.N. missions deployed in the midst of ongoing civil wars where warring parties rarely recognized nor respected the impartiality of U.N. troops. Moreover, in many instances, the Security Council and the U.N. bureaucracy were unprepared to confront the complexities of peacemaking and peacebuilding in the context of civil wars or disaster relief,

\footnotetext{
143 RoBerTs \& ZAUM, supra note 140, at 38.

144 For an account of Security Council debates during the Rwandan and the failure to intervene to prevent the ongoing genocide, see generally MiCHAEL BARNETT, EYEWITNESS TO A GENOCIDE: THE UNITED NATIONS AND RWANDA (2012).

145 See Alex Belamy \& Paul D. Williams, Trends in Peace Operations 1947-2013, in THE OXFORD HANDBOOK OF United NATIONS PEACEKEEPING OpERATIONs 13 (Joachim Koops et al. eds., 2015).
} 
which led to setbacks in the execution of Security Council-authorized interventions. ${ }^{146}$

\section{The BALANCE OF POWER AND the Foundations AND Future OF WORLD ORDER}

The structure and powers of the Security Council and the privileges extended to its Permanent Members are not the result of happenstance or historical coincidence. They are the product of an intelligent design. The architects of the post-World War II order could have established a genuine collective security organization that enforced the law, kept the peace, and protected each of its members against aggression. Indeed, the British representative at the San Francisco Conference recognized that it was not impossible to draft a "perfect Charter, perfectly logical, perfectly complete." 147 That, however, was neither attainable nor desirable. As President Roosevelt declared in his final State of the Union address: "perfectionism, no less than isolationism or imperialism or power politics, may obstruct the paths to international peace." 148 The founding fathers of the United Nations, therefore, consciously elected to construct a Great Power concert; an admittedly imperfect political apparatus beholden to the wills and whims of its Permanent Members.

This choice rested on a recognition and acceptance of two fundamental features of the international system. The first is the political pluralism of the system. The founding fathers of the United Nations accepted that we live in a world composed of states that espouse diverging, and often conflicting, policy priorities and strategies, adopt varying political systems, and implement diverse models of economic governance. ${ }^{149}$ Unless a single state or civilization establishes a global imperium, probably through the force of arms, it was presumed that political and socio-economic pluralism would endure as the defining characteristic of the international system. Second, the creators of the post-World War II order realized that material power was unevenly distributed in this politically pluralistic world. In other words, power was not

\footnotetext{
146 Chen Kertcher, The United Nations And PeAceKeeping, 1988-95 142-96 (2016).

147 United Nations Conference on International Organization, Corrigendum to Summary Report of Ninth Meeting of Committee III/1, U.N. Doc. 829, III/1/19(2) (June 7, 1945); WD 3 Statement of Questions by the Delegate of New Zealand and of Replies by the Delegate of the United Kingdom at Ninth Meeting (May 17, 1945), at 6.

148 Franklin D. Roosevelt, President of the United States, State of the Union Address (Jan. 6, 1945).

149 On the pluralistic view of the international system, see Andrew Hurrell, On Global Order: Power, Values, and the Constitution of International Society 25-56 (Oxford Univ. Press 2007).
} 
overwhelmingly concentrated in a single geographical location nor was it monopolized by states that belong to a single political or ideological camp. Therefore, maintaining world order required providing the mechanisms that would enable states that were powerful and ideologically pluralistic to coexist peacefully.

The most effective mechanism to achieve that objective, it was assumed, was the maintenance of a balance of power between the Great Powers. It was hoped that a relapse to world war could be avoided by preserving a balance between the Great Powers in the international system and by enabling those states to coexist without fundamentally threatening their respective vital interests. It appears, therefore, that the founders of the post-World War II order harbored a healthy skepticism regarding the possibility of constructing rules and institutions that would entirely negate or neutralize the role of power in inter-state relations. Instead of pursuing world peace through law, the leaders of the victorious allies sought to create political institutions that would manage — not banish— power and incentivize the Great Powers to cooperate or, at least, to compete without waging war against each other. Accordingly, the Security Council was designed to mirror and preserve a balance between the Great Powers of that era. It granted those states privileges commensurate to their power and influence and provided a forum within which they could cooperate and compete without endangering their security or encroaching on their spheres of influence. By embedding these powerful states within a common institutional framework and providing channels for communication, it was hoped that these powers would coexist and exercise restraint in the pursuit of their national interests.

These assumptions underlying the structure of the Security Council remain valid and relevant today. True, world politics has evolved dramatically since 1945. States are no longer, if they ever were, the sole actors in international relations. Non-state actors, such as corporations and NGOs, have amassed considerable power and influence; supra-state entities, such as the EU, are exercising broad authorities in political and economic policy; sub-state territorial units, such as mega-cities, states, and autonomous regions within sovereign states, are performing important roles in global governance; and even individuals and networks of individuals have become important players in world affairs. The world is also more economically integrated than in 1945.150

150 To some scholars, the second half of the twentieth century witnessed the era of "re-globalization," during which global economic integration and interaction gradually reached and surpassed pre-World War I 
Trade in manufactured goods and services has increased dramatically, especially since the $1980 \mathrm{~s} ;{ }^{151}$ the global financial market has become a principal source of funds for states; and a revolution in travel and communication technologies has affected virtually aspect of human interaction. Even on the social front, it is argued that we are witnessing a "Great Convergence" that is unifying social practices and gradually homogenizing what was a culturally heterogeneous world. ${ }^{152}$

Nonetheless, preventing Great Power war and preserving a balance of power between the most powerful states in the international system remain indispensable for maintaining world order and for the effective operation of international law. ${ }^{153}$ This is because, despite the widespread rhetoric portending its impending demise, ${ }^{154}$ the territorial state remains the primary mode of organizing human societies and the principal repository of human loyalty. In fact, the state is currently experiencing something of a comeback, ${ }^{155}$ including in regions, such as Europe, that had been assumed to have entered a cosmopolitan, post-modern, post-state era of politics. ${ }^{156}$ While the return of the state and the resurgence of nationalism associated with this phenomenon might

levels of economic interdependence. See Ronald Findlay \& Kevin H. O’Rourke, Power and Plenty: Trade, WAR, AND the World ECONOMY IN THE SECOND MillenNiUm 473 (2007).

151 “According to WTO trade statistics, the value of world merchandise exports rose from US\$2.03 trillion in 1980 to US\$ 18.26 trillion in 2011 . . . Commercial services trade recorded even faster growth over the same period, advancing from US\$ 367 billion in 1980 to US\$ 4.17 trillion in 2011 . . .." See WorLD Trade Organization, World Trade Report 2013 Factors Shaping the Future of World Trade 55 (2013).

152 Kishore Mahbubani, The Great Convergence: Asia, the West, and the Logic of One World $1-2$ (2013).

153 The claim that maintaining Great Power peace and preserving the balance of power between the leading states of the international system is necessary for the effective operation of international law is an argument that has a long pedigree in international law scholarship. Lassa Oppenheim, for instance, famously argued that, "the first and principal moral is that a Law of Nations can only exist if there be an equilibrium, a balance of power, between the members of the Family of Nations.” Benedict Kingsbury, Legal Positivism as Normative Politics: International Society, Balance of Power and Lassa Oppenheim's Positive International Law, 13 Euro. J. INT’L L. 401, 416 (2002); see also Nico Krisch, International Law in Times of Hegemony: Unequal Power and the Shaping of the International Legal Order, 16 EUR. J. INT'L L. 369 (2005) (arguing that "international law is widely assumed to depend on a balance of power").

154 James Wilets, The Demise of the Nation-State: Towards a New Theory of the State Under International Law, 17 BERKELEY J. INT’L L. 193, 194-95 (1999).

155 Clyde W. Barrow, The Return of the State: Globalization, State Theory, and the New Imperialism, 27 NEw Pol. SCI. 123, 144-45 (2005); Jacobus Delwaide, The Return of the State? 19 EUR. REV. 69, 80 (2011); John Plender, The Return of the State: How Government is Back at the Heart of Economic Life, FIN. TIMES (Aug. 21, 2008), https://www.ft.com/content/73dfc892-6fb2-11dd-986f-0000779fd18c.

156 Jakub Grygiel, The Return of Europe's Nation-States: The Upside to the EU's Crisis, 95 ForEIGN AFF. 94, 94-95 (2016). 
not be entirely welcome, territorial states remain the primary, and most potent, players in international affairs.

Furthermore, we are currently witnessing a significant shift in the configuration of world power. The U.S. unipolar moment has passed, ${ }^{157}$ China is now categorized as a peer or near-peer competitor of the United States, ${ }^{158}$ Germany and Japan are demanding permanent seats on an expanded Security Council to reflect their financial heft and political clout, ${ }^{159}$ Britain and France are performing diminished global roles, while India, Brazil, and other pivotal states are growing in wealth and influence. ${ }^{160}$ A unique feature of this ongoing global power shift is that many of the rising powers do not share the ideological orientation and normative commitments of the Western powers that constructed and led the international system during the twentieth century. As a result, the global political landscape is becoming increasingly pluralistic. States with varying - if not conflicting - interests have amassed sufficient power to demand a greater role in managing the processes of global governance and in authoring the rules of international law. ${ }^{161}$ This changing reality of international politics and the shifting distribution of power will inevitably affect the doctrinal content and institutional infrastructure of international law. As Quincy Wright recognized decades ago, "if a new political structure of the world is imminent, important modifications in the principles of international law are to be anticipated." 162

In this global political climate, "the balance of power and the policies aiming at its preservation are not only inevitable but are an essential stabilizing factor in a society of sovereign nations." 163 Maintaining the balance of power will require the Great Powers of our era, especially the United States, China, and Russia, to exercise strategic restraint. Like the Great Powers that acted in concert to preserve the peace in Europe for a century after the Napoleonic Wars, it is imperative that today’s Great Powers act in concert to preserve

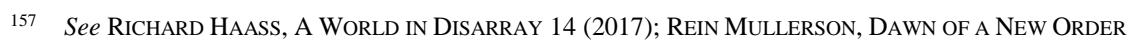
217 (2017).

158 Ryan Browne, Top US General: China Will Be 'Greatest Threat' to US by 2025, CNN (Sept. 27, 2017), https://www.cnn.com/2017/09/26/politics/dunford-us-china-greatest-threat/index.html.

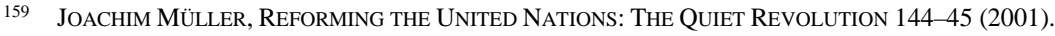

160 Phillip LiPsCy, Renegotiating THE WORLD ORDER: InSTITUTIONAL CHANGE IN INTERNATIONAL Relations 3 (2017); Oliver StuenKel, Post-Western World: How EMERging Powers ARe ReMaKing GLOBAL ORDER 195-205 (2016).

161 William Burke-White, Power Shifts in International Law: Structural Realignment and Substantive Pluralism, 56 HARV. INT’L L.J. 1, 17 (2015).

162 Quincy Wright, International Law and the Balance of Power, 37 AM. J. INT’L L. 97, 99 (1943).

163 MORGENTHAU, supra note 56, at 167. 
international peace and security. This will invariably require that these powers formulate inter se some basic understandings of the normative prerequisites of world order and that they achieve a modus vivendi in their bilateral relations to refrain from challenging their respective vital interests and respective spheres of influence. Specifically, the Great Powers must articulate a clear understanding of their vital interests and strategic priorities, especially in regions - such as the East and South China Seas, Eastern Europe, Central Asia, and the Middle East - where the potential is highest for collisions between the Great Powers. As they formulate understandings of their vital interests, the Great Powers must communicate regularly, both bilaterally and through multilateral forums like the Security Council, to ensure that they are aware of their respective vital interests and to reach understandings about how to accommodate and coordinate these interests. ${ }^{164}$

This is the indispensable foundation of world order for the foreseeable future. It will create a permissive political environment in which the Great Powers could cooperate to address intractable global problems, such as civil wars, protracted conflicts, arms control, climate change, natural disasters, and communicable diseases. Unfortunately, the outcome of Great Power cooperation will almost always be an imperfect solution, a temporary fix, or an uneasy compromise. At times, accommodating the interests of the Great Powers may even generate injustices and iniquities. Nonetheless, politics is the art of the possible. While one may dream of a world in perpetual peace, the reality is that we live in a pluralistic world where power is diffuse and disaggregated and where humanity is not united by a single moral compass.

\footnotetext{
164 As Avery Goldstein explains, one of the challenges facing international peace and security is that the Great Powers, especially the United States and China, have not articulated and communicated a clear understanding of their respective vital interests, especially in areas such as the South and East China Seas. Therefore, Goldstein argues that it is essential that these powers formulate and communicate to each other “'redlines' that cannot be crossed without risking conflict," which would enable these powers to exercise greater restraint in their relations. Avery Goldstein, China's Clear and Present Danger, 92 FoREIGN AFF. 136, 137 (2013).
} 